DOI: https://doi.org/10.15407/preislamic2021.02.027

UDC $94(32)$

\title{
EVOLUTION OF THE OFFICE OF “GOD'S WIFE” IN ANCIENT EGYPT
}

\author{
N. M. Bondarenko \\ MA Student \\ Department of Ancient and Medieval History, the Faculty of History, \\ Taras Shevchenko National University of Kyiv \\ 60, Volodymyrska Str., Kyiv, 01601, Ukraine \\ nataliaukraine22@gmail.com
}

The article is devoted to the study of the influence of the religious female title of "God's Wife", which was the highest religious female title in Ancient Egypt. Throughout the history of different Dynasties, it took on political overtones. As the prestige of this title grows, so does the role and status of women in society. It reached its apogee in the $18^{\text {th }}$ dynasty, during the reign of the female pharaoh Hatshepsut. We can trace the evolution of the title and the changes in its functionality. The most interesting were the conditions and reasons for these changes.

The title "God's Wife of Amun" gained a special rise during the reign of the $18^{\text {th }}$ Dynasty and the Third Intermediate Period. King Ahmose I, the founder of the $18^{\text {th }}$ Dynasty, gave this title to his wife Ahmose-Nefertari. After the reign of Thutmose III, the title lost its initial influence. During the reign of the $19^{\text {th }}$ Dynasty, it was owned by only two women - the wives of Ramesses I and Seti I. In the Third Intermediate Period, the queen, usually the king's daughter, had to ensure the king's influence already in Thebes. Later, with the increase of the priesthood of Amun, the God's Wife took more and more care of the temple in Karnak. As for the contribution of the God's Wife to the history of Ancient Egypt, the most significant were the cult temples. The main task of the queens, the holders of the title "God's Wife", was to ensure the support of the king and the ruling dynasty. At the same time, it allowed women in Ancient Egypt to gain unprecedented religious and political influence.

Keywords: "God's Wife", title, Thebes, High Priest of Amun, Ancient Egypt, gender, women in Ancient Egypt

The role of women in Ancient Egypt remains relevant as the focus of the study among Egyptologists. During the "Golden Age", the New Kingdom (ca. 1550-1069 BC)1, the female title "God's Wife of Amun", Hm.t nTr n I mn, was one of the most important and influential. Most notably, the "God's Wife of Amun" should not be confused with the "God's Wife", that was also quite popular in the early period [Ayad 2009, 4]. Primarily, the "God's Wife" was used to an abstract deity, not to a specific one. The combination of religious and political responsibilities, as well as widespread impact on society changed women's status and role in Egyptian history.

The role of the title "God's Wife of Amun" reached its apogee in the New Kingdom. The women who carried it became the high priestesses of the cult of Amun. In order to better understand the importance of this title, consideration must be given to the history of its evolution from the first mention to the last holder.

Despite the fact that the "God's Wife" was one of the most significant religious female titles, the first mention of it dates back to the First Intermediate Period (ca. 2160 2055 BC). The other three important female titles were: Hm.t nTr, i.e. "God's Wife",

\footnotetext{
${ }^{1}$ See chronology: [Shaw 2000, 480-489].
} 
dwAt nTr, i.e. "Divine Adorer", "Divine Adoratrice", or "Divine Worshipper", and Drt nTr, i.e. "God's Hand". The last one particularly emphasized the sexual role of the title. Originally, there was no link to a specific god, therefore the general word "god", nTr [Gardiner 1957, 502], was used.

More officially, the title appears in the New Kingdom, at the beginning of the $18^{\text {th }}$ Dynasty (ca. 1550-1295 BC). The founder of the Dynasty, Ahmose I, gave the title "God's Wife of Amun" of a political nature to his wife, Ahmose-Nefertari.

As noted above, the title was first given in the abbreviated form "God's Wife", without reference to a specific deity. It is known that in the Middle Kingdom this title was held by two non-royal women, Iy-meret-nebes and Neferu, presumably they were priestesses. In that period, the title became more specific. The first god who received a "god's wife" priestess was the god Min.

Apparently, the "God's Wife" served as great support for the power of king during the unstable periods of ancient Egyptian history. Such assistance was needed, for example, during the founding of the new Dynasty by Ahmose I (ca. 1550-1525 BC), or to legitimize Hatshepsut's claim to the throne (ca. 1479-1458 BC).

According to the texts of the Donation stela from Karnak, the title "God's Wife of Amun" was given to Ahmose-Nefertari by her husband Ahmose I. Her mother, Ahhotep, was probably posthumously awarded the title of "God's Wife of Amun" [Gitton 1975] and Ahmose-Nefertari later passed it on to her daughter, Meritamun, the wife-sister of Amenhotep I. During the reign of Thutmose I, Hatshepsut inherited this title from her mother queen Ahmose, following the tradition. Despite the fact that queen Ahmose was never called a King's Daughter, Hatshepsut portrayed her with all the necessary attributes of the "God's Wife of Amun" [Robins 1993, 152], thus, emphasizing Hatshepsut's hereditary right to possess this title.

Meritamun died when Hatshepsut was about 10 years old, and the princess inherited this title in young age. Probably, it helped her to keep the power for so long in a consequence. Later, the female pharaoh passed on the title to her daughter, princess Neferura as mentioned in the Red Chapel at Karnak Temple, and on the third terrace in Deir el-Bahari, since Neferura was often mentioned in the records as the "God's Wife of Amun", even without mentioning her name. This title, undoubtedly, emphasized the high status in society [Cooney 2018, 141-144]. The last mention of Neferura appeared on the stela from Serabit el-Khadim, dated by regnal year 11 of Hatshepsut. Neferura was unmarried and had no children [Cooney 2015, 176-179]. Hatshepsut actively used the cult of the god Amun, spreading the legend of her divine origin. The period of her reign was the stage of final formation of the title "God's Wife of Amun".

Satiah, the wife of Thutmose III (ca. 1479-1425 BC), also was "God's Wife". But her mother, Ipu, a royal nurse, did not have this title, so she could not pass it on. Thutmose III's other wife, Hatshepsut-Meryetre, served as the "God's Wife" and "God's Hand". Their daughter, Meritamun, also had the same title.

By conferring the title "God's Wife of Amun" on his wife Ahmose-Nefertari, king Ahmose I automatically emphasized her political and religious influence. During the New Kingdom the queen became a strong partner for the pharaoh in a difficult period. She had the right to dispose of the funding received after the rituals, which was previously allowed only to priests. Perhaps this in some way diminished the role of the priesthood, although the development of the cult of Amun does not allow us to say it with confidence. 
According to the scenes on the reliefs of the Red Chapel [Lacau 1977, 331], the "God's Wife of Amun" had the following responsibilities:

- Participation in daily rituals dedicated to the god Amun.

- Swimming in the sacred lake with the priests before the rituals.

- Staying in special places of the temple.

- Declaiming the menu for the god Amun.

- Burning wax figures of the enemies of Amun to maintain balance.

- Shaking sistrum in front of the sacred statue of the god Amun.

An important fact is that much of the income went directly to the Queen but not to the temple.

After Hatshepsut's death, when Thutmose III came to the throne, the title "God's Wife of Amun" was banned by the king. It did not appear in official texts until the Third Intermediate Period (ca. 1069-664 BC). Women were temporarily removed from the possibility of gaining at least some power, and this prevented a recurrence of the case with Hatshepsut. There was no evidence of using the title "God's Wife" during the reigns of Akhenaten (ca. 1352-1336 BC), his successors Tutankhamun (ca. 1336-1327 BC) and Horemheb (ca. 1323-1295 BC).

At the end of the $20^{\text {th }}$ Dynasty (ca. 1189-1069 BC), corruption was widespread, as well as general economic instability and political unrest. Thus, under Rameses IX (ca. 1126-1108 BC) there were also cases of theft of royal tombs. Under the impact of all these factors, the influence of the royal power and king's entourage on the solution of political and social issues rapidly decreased. The High Priest of Amun, Hm nTr tp n I mn, received more authority [Grimal 1992, 288-290]. During the reign of the Ramses XI (ca. 1099-1069 BC), there was a military conflict between the high priest Amenhotep and the Viceroy of Kush, Panehsy. The last one retreated to Nubia in 1087 BC. After his death, the territory was ruled by another high priest of Amun - Herihor. He was the person who became de facto the ruler of Upper Egypt.

In such an unstable situation, Rameses VI (1143-1136 BC) asked his daughter Isis to go to the residence in Thebes and receive the title "God's Wife of Amun", which she owned for about 25 years [Tamas 1995, 7-11]. She was mediated by another Isis, the wife of Rameses III (ca. 1184-1153 BC), who also combined the titles "God's Wife of Amun" and "Divine Worshipper". Also, she was the only one who, like Ahmose-Nefertari of her time, recorded the full version of the title, Hm.t nTr n I mn [Gosselin 2007, 148-154].

At the beginning of the Third Intermediate Period, during the reign of the pharaoh Smendes (ca. 1069-1043 BC), instability and fragmentation were observed. There were three women who held the title "Divine Adorer" during the early Third Intermediate Period: Maatkara (I) Mutemhat (a daughter of Pinedjem I, and queen Henuttawy, $21^{\text {th }}$ Dynasty), Henuttawy (a daughter of high priest of Amun Pinedjem II and Isetemkheb), and Karomama Meritmut (a daughter of the High Priest of Amun Nimlot and Tentsepeh, $22^{\text {nd }}$ Dynasty). Maatkara (I) Mutemhat combined dwAt $n T r$ and Hm.t nTr titles and wrote the name in the cartouche, which later became characteristic of the $23^{\text {rd }}$ Dynasty [Gosselin 2007, 237]. Karomama was also the earliest known "God's Wife of Amun", who used female versions of the king's titles: "Daughter of Re" and "Mistress of tiaras/performances". Later, during the $9^{\text {th }}-6^{\text {th }}$ centuries BC, the $23-26^{\text {th }}$ Dynasties (ca. $818-525 \mathrm{BC}$ ), it is known that only five women held the title "God's Wife of Amun". Again in an unstable period. These were princesses Shepenwepet I, Amenirdis I, Shepenwepet II, as well as Saite Nitocris I and Ankhnesneferibre. 
Shepenwepet I, daughter of Osorkon III (777-749 BC), was the only "God's Wife of Amun" since the time of Isis, daughter of Rameses VI. Other women before Shepenwepet I held just the title "Divine Worshipper". The texts do not mention her husband or children, so she may have been single.

With the arrival to Egypt, the Nubians realized the importance of the "God's Wife of Amun", and established authority in Thebes through political potential [Kitchen 1995, $352,359]$. In the 740's BC Shepenwepet I shared her power to Thebes as a co-ruler of king. The queen wrote her name in cartouches, combining it with the title "Mistress of Two Lands". She became a counterweight to the priesthood. The next one, Amenirdis I, the daughter of pharaoh Kashta (ca. 760-752 BC) and Queen Pebatjma, was the first known royal woman, since the time of Ahmose-Nefertari, who reunited all three titles "God's Wife", "Divine Adorer", and "God's Hand" [Lohwasser 2001, 61-76]. She was adopted and passed the title from Shepenwepet I. Amenirdis I ruled as High Priestess during 714-700 BC. Subsequently, the title "God's Wife of Amun" was transferred to Shepenwepet II.

The merger of religious and political functions of the "God's Wife of Amun" took place in the Third Intermediate Period. If earlier, according to the traditional notion, "God's Wife of Amun" had to be unmarried and childless, now it became especially relevant. And ceased to be purely symbolic. Such "celibacy" protected against encroachments by possible heirs on the power and priesthood of Amun.

During the reign of the $26^{\text {th }}$ Dynasty (ca. 664-525 BC), the most known women were Nitocris II (ca. 665-585 BC) and Ankhnesneferibre (ca. 595-525 BC) [Kitchen 1986, 403-405]. However, their functions were mainly concentrated only in the religious sphere (building temples in Karnak, performing rituals, celebrating the Sed-festival, etc.). As for the reduction of the role of the title, the fact that its purpose was often purely symbolic speaks for itself. These princesses received powers in early childhood, and certainly could not somehow manage political affairs at that age. They were often accompanied by mothers or relatives. The last known "God's Wife of Amun" was Ankhenesneferibre [Gardiner 1961, 354], daughter of Psamtik II (ca. 595-589 BC) and Queen Takhuit, during 595-525 BC. She was adopted by Nitokris II. Thus Ankhenesneferibre, in the $26^{\text {th }}$ Dynasty, completed the long history of the "God's Wife".

\section{Conclusions}

In the Middle Kingdom, there was a "predecessor" of the title "God's Wife of Amun" without reference to a specific deity, and later to the gods Pta or Min. The title flourished in the New Kingdom, particularly during the reign of the female pharaoh Hatshepsut. This was due to the process of legitimizing her power and the rise of the cult of Amun. The title disappeared during the reign of Thutmose III, and at the time of the new religious reform of Akhenaten it lost its relevance. Before the revival of the $20^{\text {th }}$ Dynasty, the only one who held this title was Tia, the wife of Thutmose IV.

In the Third Intermediate Period, the formation and further development of the title "God's Wife of Amun" started having the most effective and long-lasting impact on the status and role of women in Ancient Egypt. It also became the most powerful political tool in the Third Intermediate Period. This was confirmed by the appearance of the queen's name in cartouches, and sometimes even wearing a crown.

The king's power weakened after the reign of Ramses III, after the coup, which may have been arranged by one of his wives. Then the de facto real power passed to the High Priest of Thebes, who managed not only the land, workshops, farms, and provision in the 
Karnak and Medinet Habu temples, but also the region's economy. Therefore, at the end of the New Kingdom - the beginning of the Third Intermediate Period, power passes from the hands of King to the Priesthood of Amun. Meetings and communication between priests and the people remained important. The oracles influenced the people, and the priesthood controlled oracles. That's why gradually the "God's Wife of Amun" began to supervise the priesthood.

As of the $26^{\text {th }}$ Dynasty, the "God's Wife of Amun" was already superior in status to the High Priests of Amun. The priesthood controlled 2/3 of the temple land, $90 \%$ of the ships, and $80 \%$ of the farms, and when they received this, they gained control of all Egypt. Also, the presence of the "God's Wife" ensured the stability of the succession of adoption.

This is exactly the situation we have with the evolution of the title "God's Wife" in Ancient Egypt from its founding to the holder. This also had an impact on the status of women in society and their rights.

\section{REFERENCES}

Ayad M. (2009), God's Wife, God's Servant: The God's Wife of Amun (ca. 740-525 $B C)$, Routledge, London.

Basson D. (2012), The Goddess Hathor and the Women of Ancient Egypt, Stellenbosch University, Stellenbosch.

Bradshaw A. (2017), Female Power in the New Kingdom, University of Kent, Kent, U.K.

Bryan B. M. (2005), Property and the God's Wives of Amun, Center for Hellenic Studies, Harvard University, Cambridge.

Capel A. K. (1996), Mistress of the House, Mistress of Heaven: Women in Ancient Egypt, Hudson Hills Press with Cincinnati Art Museum, New York.

Cooney K. (2015), The Woman Who Would Be King: Hatshepsut's Rise to Power in Ancient Egypt, Broadway Books, New York.

Cooney K. (2018), When Women Ruled the World: Six Queens of Egypt, National Geographic, Washington D.C.

David R. and A. E. (2003), A Biographical Dictionary of Ancient Egypt, Routledge, London.

Gardiner A. (1957), Egyptian Grammar: Being an Introduction to the Study of Hieroglyphs, Griffith Institute, Oxford.

Gosline S. L. (1996), Female Priests: A Sacerdotal Precedent from Ancient Egypt, Journal of Feminist Studies in Religion, Indiana University Press, Bloomington.

Graves-Brown C. (2010), Dancing for Hathor: Women in Ancient Egypt, Continuum, New York.

Graves-Brown C. (2008), Sex and Gender in Ancient Egypt. "Don Your Wig for a Joyful Hour", Classical Press of Wales, Swansea.

Grimal N. (1992), A History of Ancient Egypt, trans. I. Shaw, Blackwell, Oxford.

Kitchen K. A. (1995), Third Intermediate Period in Egypt (1100-650 BC), Aris \& Phillips, Warminster.

Myśliwiec K. (1985), Eighteenth dynasty before the Amarna period, E. J. Brill, Leiden.

Redford D. B. (1967), History and Chronology of the Eighteenth Dynasty of Egypt: Seven Studies, University of Toronto Press, Toronto.

Robins G. (1993), Women in Ancient Egypt, Harvard University Press, Cambridge, MA. Sabbahy L. (2017), Gender, Pharaonic Egypt, American University in Cairo, Cairo. Shaw I. (2003), The Oxford History of Ancient Egypt, Oxford University Press, Oxford. 
N. M. Bondarenko

Tyldesley J. (2006), Chronicle of the Queens of Egypt: From Early Dynastic Times to the Death of Cleopatra, Thames \& Hudson, London.

Tyldesley J. (1994), Daughter of Isis. Women of Ancient Egypt, Penguin, London.

Vivante B. (ed.) (1999), Women's Roles in Ancient Civilizations: A Reference Guide, Greenwood, Westport, CT.

Watterson B. (1991), Women in Ancient Egypt, St. Martin's Press, New York.

\section{Н. М. Бандарэнка \\ РАЗВІЦЦЁ РЭЛІГІЙНАГА ТЫТУЛА “ЖОНКА БОГА” Ў СТАРАЖЫТНЫМ ЕГІПЦЕ}

Артыкул прысвечаны даследаванню ўплыву тытула "Жонка бога". “Жонка бога" - гэта найвышэйшы рэлігійны жаночы тытул у Старажытным Егіпце. На працягу кіравання розных дынастый ён усё больш набываў палітычную афарбоўку. 3 ростам прэстыжу гэтага тытула ўзрастаюць роля і статус жанчын у грамадстве. Тытул дасягнуў свайго апагею падчас праўлення жанчыны-фараона Хатшэпсут, XVIII дынастыя. Мы можам прасачыць эвалюцыю тытула і змены яго функцыянальнасці. Асаблівай увагі патрабуюць умовы і прычыны гэтых зменаў. Тытул “Жонка бога Амона” атрымаў адмысловую папулярнасць падчас кіравання XVIII дынастыі і Трэцяга пераходнага перыяду. Фараон Яхмас I, заснавальнік XVIII дынастыі, дараваў гэты тытул сваёй жонцы Яхмес-Нефертары. Пасля кіравання Тутмаса III тытул страціў свой першапачатковы ўплыў. Пры XIX дынастыі ім валодалі толькі дзве жанчыны - жонка Рамзэса I і жонка Сеці I. У Трэці пераходны перыяд царыца, звычайна дачка цара, павінна была забяспечыць уплыў цара ўжо ў Фівах. Пазней, з узмацненнем святарства Амона, “Жонка бога” ўсё больш клапацілася пра храм у Карнаку. Што тычыцца ўкладу “Жонкі бога” ў гісторыю Старажытнага Егіпта, то самым значным былі культавыя храмы. Асноўная задача царыц, уладальніц тытула “Жонка бога”, заключалася ў забеспячэнні падтрымкі фараона і кіруючай дынастыі. У той жа час гэта дазволіла жанчынам Старажытнага Егіпта атрымаць беспрэцэдэнтны рэлігійны і палітычны ўплыў.

Ключавыя словы: “Жонка бога”, тытул, Фівы, Найвышэйшы Святар Амона, Старажытны Егіпет, гендэр, жанчыны ў Старажытным Егіпце

\section{Н. М. Бондаренко}

\section{Розвиток релігійного титулу “Дружина бога” у Стародавньому Єгипті}

Стаття присвячена дослідженню впливу релігійного жіночого титулу “Дружина бога”. Це найвищий релігійний титул цариці у Стародавньому Єгипті. Протягом правління різних династій він все більше набував політичного характеру. Зі зростанням престижу цієї посади зростає також роль і статус жінки у суспільстві. Свого апогею впливу титул досяг під час правління жінки-фараона Хатшепсут, XVIII династія. Ми можемо простежити еволюцію титулу та зміни його функціональних можливостей. Особливої уваги потребують умови та причини цих змін. Титул “Дружина бога" набув особливого піднесення за часів правління XVIII династії та Третього перехідного періоду. Фараон Яхмос I, засновник XVIII династії, дарував цей титул своїй дружині Яхмес-Нефертарі. Після правління Тутмоса III титул втратив свій початковий вплив. За XIX династії ним володіли лише дві жінки - дружини Рамзеса I і Сеті I. У Третій перехідний період цариця, зазвичай донька царя, мусила забезпечувати збереження впливу фараона у Фівах. Пізніше, зі збільшенням авторитету священства Амона, Дружина бога дедалі більше піклувалася про храм у Карнаці. Що стосується внеску Дружини бога в історію Стародавнього Єгипту, то найзначнішим були масові культові храми. Головне завдання цариці, володарки титулу “Дружина бога”, полягало у підтримці фараона та забезпеченні стабільності панівної династії. Водночас це дозволило жінкам у Стародавньому Єгипті отримати безпрецедентний релігійний та політичний вплив.

Ключові слова: “Дружина бога”, титул, Фіви, Верховний жрець Амона, Стародавній Сгипет, гендер, жінки в Стародавньому Сгипті 